\title{
Cefuroxime Axetil
}

National Cancer Institute

\section{Source}

National Cancer Institute. Cefuroxime Axetil. NCI Thesaurus. Code C28918.

A second generation semi-synthetic cephalosporin and a beta-lactam antibiotic with bactericidal activity. Cefuroxime's effect is dependent on its binding to penicillin-binding proteins (PBPs) located in the bacterial cytoplasmic membrane. Binding results in the inhibition of the transpeptidase enzymes, thereby preventing cross-linking of the pentaglycine bridge with the fourth residue of the pentapeptide and interrupting consequent synthesis of peptidoglycan chains. As a result, cefuroxime inhibits bacterial septum and cell wall synthesis formation. 